\title{
Blood Mercury Levels in Relation to Overweight in Korean Children and Adolescents: Results From The Korean National Health and Nutrition Examination Survey 2010-2013
}

KY YOUNG CHO ( $\square$ choky96@hanmail.net )

Hallym University Kangnam Sacred Heart Hospital

\section{Research Article}

Keywords: Mercury, Overweight, Adolescent, Nutrition Surveys

Posted Date: January 18th, 2021

DOI: https://doi.org/10.21203/rs.3.rs-146410/v1

License: (a) (1) This work is licensed under a Creative Commons Attribution 4.0 International License. Read Full License 


\section{Abstract}

Background: Previous researches for adults have demonstrated a substantial role of mercury exposure in the development of overweight and obesity development, but those findings are inconsistent. Although children and adolescents are more susceptible to the toxic effect of mercury compared to adults, the research of overweight and obesity related to mercury exposure in children and adolescent is scarce. This study aimed to investigate the association of blood mercury levels with body mass index (BMI) in Korean children and adolescents.

Methods: The cross-sectional data analyzed were obtained from 1327 participants (age: 10-18 years, 672 males and 655 females) who completed the Korean National Health and Nutrition Examination Survey 2010-2013. The adjusted covariates were age, sex, household income, total intake of seafood in the previous 24 hours, and current status of alcohol consumption and smoking.

Results: The adjusted geometric mean blood mercury level was $2.19 \mu \mathrm{g} / \mathrm{L}$ and increased significantly in the overweight group and the highest seafood consumption quartile compared with the level in the normal weight group and lowest seafood consumption quartile, respectively $(P<$ 0.001). The adjusted blood mercury levels were significantly positively correlated with BMI in all participants and females $(P<0.05)$. When stratified by age and sex, all participants and males in the highest blood mercury level quartile were at higher risk of overweight than those in the lowest quartile (odds ratios [95\% confidential intervals, Cls]: 1.78 [1.06-2.98], and 2.06 [1.01-4.23], respectively) after adjusting for the covariates $(P<0.05)$. Receiver operating characteristic analysis of blood mercury levels for predicting overweight revealed that the area under the curve was $0.603(P<0.001)$.

Conclusions: Our study suggested a significant association between mercury exposure and the risk of overweight in Korean children and adolescents.

\section{Background}

The prevalence of overweight and obesity in children and adolescents has increased over the past decade [1]. Overweight and obesity in children and adolescents lead to critically important health conditions, including hypertension, type 2 diabetes mellitus, cardiovascular complications, and psychological problems, which can continue into adulthood [2]. Various factors affect overweight and obesity, including genetic factors, lifestyle, cultural factors, and environmental factors [3]. An imbalance between caloric intake and physical activity has been considered a principal cause of overweight and obesity [4].

Some research has demonstrated a substantial role of environmental factors in the development of overweight and obesity [5]. In particular, a significant association between mercury exposure and obesity development has been demonstrated. A study of 200 healthy adults aged 30 to 64 years showed a significant association between blood mercury levels and visceral adipose tissue [6]. In a study of 2,114 adults, a significant relationships were also demonstrated between blood mercury levels and body mass index (BMI) and waist circumference [7]. However, another study reported that no significant relationships were noted between blood mercury levels and adipose tissue content [8]. Moreover, research on U.S. nonpregnant adults and children revealed that blood mercury levels were inversely related to BMI [9]. Previous findings on the association of mercury exposure with overweight and obesity are inconsistent.

Mercury generally exists in the environment, and most elemental and inorganic mercury exposure occurs by breathing air containing elemental mercury vapor in some occupations or through devices containing mercury, such as thermostats or thermometers [10, 11]. In the human body, $80 \%$ to $90 \%$ of organic mercury intake is attributed to fish and shellfish intake, and $75 \%$ to $90 \%$ of organic mercury existing in fish and shellfish is in the form of methylmercury, which is known to have the strongest toxicity in humans [12]. Long-term exposure to high levels of methylmercury causes primarily nervous system effects, including disturbances in vision, hearing and speech, as well as tingling and numbness in fingers and toes, lack of coordination and muscle weakness [10,13]. Not only heavy exposure but also relatively low-level exposure to mercury has been related to increased risk of cognitive impairment, hypertension, alteration of heart function, and renal dysfunction in children and adults [14]. Children and adolescents are more susceptible to the toxic effect of mercury than adults, because their nervous systems are still developing and may be more vulnerable [15]. Various risk factors, such as age, sex, genetics, and culture, are associated with elevated blood mercury levels [16]. Increased BMI can also be associated with elevated blood mercury levels; however, research on the relationship of BMI with blood mercury status in children and adolescents is insufficient.

The purpose of this study was to investigate the association of blood mercury levels with BMI in Korean children and adolescents using data from the Korean National Health and Nutrition Survey (KNHANES) 2010-2013.

\section{Materials And Methods}

\section{Study Design}


The KNHANES is a series of nationally representative population-based cross-sectional surveys about health and nutritional status that have been conducted using a stratified, multistage, and probability sampling design by the Korea Centers for Disease Control and Prevention (CDC) [17]. Our study used data from the questionnaire, physical examination components, laboratory indices, and diet assessment of the KNHANES V 1-3 and VI-1 (2010-2013). Among an initial enrolled sample of 15,261 men and 18,291 women, we excluded those who were aged younger than 10 years and older than 19 years; had no data on anthropometric measures; had no responses on the questionnaires for household income, current status of alcohol consumption and smoking, and total amount of seafood consumed; and had no measurement of blood mercury levels or hematocrit (Hct) (Figure 1). The final number of participants was 1,327 (10-18 years of age, 672 males and 655 females), and the participants were divided into normal and overweight groups. Overweight was defined as a BMI $\geq 85^{\text {th }}$ gender and age-specific percentiles based on the 2017 Korean growth chart [18]. The rest of the participants composed the normal group. BMI was defined as the participants' weight in kilograms divided by the height in meters squared $\left(\mathrm{kg} / \mathrm{m}^{2}\right)$. Participants were additionally divided into male and female groups.

\section{Measurements of Blood Mercury Levels in Whole Blood}

To measure the levels of mercury in whole blood, 3-mL blood samples were obtained from the participants after an 8-hour overnight fast. The blood mercury levels were measured using the gold amalgam collection method with a Direct Mercury Analyzer 80 (DMA-80, Milestone, Bergamo, Italy) in the Neodin Medical Institute (Seoul, South Korea), a central laboratory certified by the Korean Ministry for Health and Welfare [19]. For internal quality assurance and control, commercial reference material was used (Lyphochek ${ }^{\circledR}$ Whole Blood Metals Control; Bio-Rad, Hercules, CA, USA) with coefficients of variation of 1.59-4.86\% among four reference samples. For external quality assurance and control, the Neodin Medical Institute was approved by the German External Quality Assessment at Friedrich-Alexander University and by the Quality Assurance Program at the Korea Occupational Safety and Health Agency. The limit of detection for blood mercury using this method was $0.158 \mu \mathrm{g} / \mathrm{L}$, and no participants presented a blood mercury concentration below this level in this study. Blood mercury levels were categorized into quartiles (Qs) and stratified by sex and age. Q4 of blood mercury levels was defined as the highest value.

\section{Determination of Covariates}

Data were obtained from the questionnaires of sociodemographic, lifestyle and dietary factors from the KNHANES. Household income was determined according to the quartile values of equalized household income (total household income divided by the square root of the number of household members) [20]. The current status of alcohol consumption was classified as drinker or nondrinker, which was defined according to consuming alcohol more than once in the last month. The current status of smoking was classified as smokers or nonsmokers, which was defined according to smoking more than once in the last month. The total amount of fish, shellfish, and seaweed (seafood) consumed within the previous 24 hours was obtained using a 24-h dietary recall questionnaire administered by a trained nutritionist. Additionally, Hct was used as a covariate and categorized into quartiles. For all quartile categorizations, Q4 is defined as the highest value for each variable.

\section{Statistical Analysis}

Statistical analyses were performed using SPSS statistical software (version 22; IBM Co., Chicago, IL, USA) and visualized by R program (version 3.6.2). Logarithmic transformation was applied to skewed variables to improve the normality of the distribution. The complex weighted sample descriptive procedure was used for evaluating the numerical variables, and the complex weighted sample crosstabs procedure was used for evaluating the categorical or ordinal variables using weights provided by the KNHANES. The complex weighted samples general linear model was used to calculate the geometric means and 95\% confidence intervals (Cls) to compare the blood mercury levels between the groups of study variables. The regression coefficient ( $95 \% \mathrm{Cls})$ of the association between blood mercury levels and BMI was calculated by the complex weighted samples general linear model after controlling the covariates, including the sociodemographic factors (sex, household income), dietary factors (seafood consumption), lifestyle factors (alcohol consumption, smoking), and blood Hct levels. Multivariate weighted logistic regression analysis was used to determine the odds ratios (ORs) and $95 \%$ Cls for predicting the risk of overweight, adjusted for the same covariates. Participants in Q1 of blood mercury levels were considered as the reference group. A receiver operating characteristic (ROC) curve was constructed to evaluate the performance of blood mercury levels in predicting overweight. The prevalence of overweight according to the quartile of blood mercury levels was calculated from the complex weighted sample crosstabs procedure. A two-tailed $P$ value $<0.05$ was considered statistically significant. $P$ values for the trend test were performed in the overweight group across increasing blood mercury levels.

\section{Results}

\section{The Characteristics of the Participants}


This cross-sectional survey was conducted among 1327 participants (672 males and 655 females) who completed the KNHANES, $2010-2013$. The characteristics of the participants are presented in Table 1. Among all participants, no significant differences between the normal and overweight groups in age, 3-year interval age groups, each survey year, blood Hct levels, household income quartiles, or the current status of drinking and smoking were found for males or females (Table 1). The number of participants in the overweight group was 267 (20.1\%), and in the normal group, the number was 1060 (79.9\%). As expected, weight, BMI, and waist circumference were significantly higher in the overweight group than in the normal group among all participants, males and females $(P<0.05$, Table 1$)$. The overweight group showed significantly higher adjusted geometric mean blood mercury levels than the normal group among all participants, males, and females $(P<0.001$, Table 1$)$. The overweight group showed significantly higher intake of seafood in the previous 24 hours than the normal group among females $(P<0.05$, Table 1). Among all participants, the abdominal circumference in the male group was significantly higher than that in the female group (male: $71.62 \pm 0.48$, female: $67.75 \pm 0.41, P=0.000$ ). The blood Hct levels in the male group were significantly higher than those in the female group (male: $43.44 \pm 0.15$, female: $39.89 \pm 0.12, P=0.000)$.

\section{Blood Mercury Levels According to Participants' General Characteristics}

Table 2 presents the geometric means and 95\% Cls of blood mercury levels according to participants' general characteristics. The geometric mean (95\% Cls) of blood mercury levels in all participants, males, and females was 2.19 (2.06-2.26), 2.18 (1.98-2.38), and 2.14 (1.91-2.36) $\mu \mathrm{g} / \mathrm{L}$, respectively, after controlling for age, sex, total intake of seafood in the previous 24 hours, household income, and current status of drinking and smoking. No significant differences in crude or adjusted blood mercury levels were found between the male and female groups. The geomean of blood mercury levels was significantly higher in the overweight group than in the normal group among all participants and the male group but not in the female group after adjusting for covariates $(P<0.01$, Table 2$)$. The Q3 and 4 of blood Hct levels showed significantly higher crude and adjusted geomean of blood mercury levels than the Q1 of blood Hct levels in all participants and the male group $(P<0.05$, Table 2). Q4 of a total amount of seafood consumed in the previous 24 hours showed significantly higher crude and adjusted blood mercury levels than Q1 among all participants, males and females $(P<0.05$, Table 2). No significant differences in blood mercury levels were found according to the current status of drinking and smoking (Table 2 ).

\section{Associations between Blood Mercury Level and BMI}

Logarithmically transformed blood mercury levels were significantly positively correlated with logarithmically transformed BMI in unadjusted and adjusted models of all participants and females $(P<0.05$, Table 3, Figure 2$)$. In the male group, unadjusted and adjusted age and sex models showed significantly positive associations between logarithmically transformed blood mercury levels and logarithmically transformed BMI $(P<0.05$, Table 3).

\section{Logistic Regression and ROC Curve Analysis for Overweight}

When stratified by age and sex, blood mercury levels were significantly associated with overweight in all participants (OR=1.78, 95\% Cls: $1.06-$ 2.98, $P$ for trend=0.05), males (OR=2.06, 95\% Cls: $1.01-4.23, P$ for trend=0.024), and females $(\mathrm{OR}=1.52,95 \% \mathrm{Cls}$ : $0.74-3.12, P$ for trend=0.038) after adjusting for covariates (Table 4). ROC analysis of blood mercury levels for predicting overweight in all participants showed that the area under the curve (AUC) was 0.603 (95\% Cls: 0.566-0.640, $P=0.000$, Figure 3 ).

\section{Prevalence of Overweight associated with the Quartile of Blood Mercury Levels}

In all participants, males and females, the prevalence of overweight participants increased with the elevation of the blood mercury quartiles $(P$ $<0.01$, Table 5).

\section{Discussion}

In this study, we demonstrated that elevated blood mercury levels were associated with risks for overweight in Korean children and adolescents after adjusting for possible potential confounders according to data from the KNHANES.

Several studies in adults have shown that BMI was associated with blood mercury levels; however, they showed inconsistent results [5, 6, 9]. Moreover, few studies have been performed on children and adolescents, and these studies also showed inconsistent results [9]. One study showed that obesity is associated with blood mercury levels in children and adolescents, but this previous study had a limitation in regard to a lack of adjustment for seafood consumption, whereas our study performed this adjustment [21]. Another study in children revealed that BMI was inversely related to blood mercury levels, suggesting differences in mercury metabolism related to BMI between adults and children [9]. Our study revealed that blood mercury levels showed a significant positive association with BMI after adjusting for covariates, including seafood consumption. Additionally, participants in the highest quartile of blood mercury levels were at higher risk of overweight than those in the lowest quartile, and the blood mercury levels exhibited acceptable performance in predicting overweight in the ROC analysis. These results

Page $4 / 16$ 
suggested that mercury exposure could result in an increased risk of overweight in Korean children and adolescents. Blood mercury levels could be related to age, pattern of seafood consumption, genetics involved in mercury clearance, and race [22]. Our study could provide additional valuable information on blood mercury levels associated with Korean overweight children and adolescents.

The most commonly accepted methods of assessing mercury exposure are to test urine or blood, which usually measure the level of total mercury (elemental, inorganic and organic) [23]. The blood mercury level reflects the burden of organic mercury that has accumulated in the body, whereas urinary mercury reflects exposure to inorganic mercury [23]. For most people, an elevated blood mercury level is associated with eating fish and other seafood containing organic mercury. In a study of a general Korean population, seafood intake during the previous 3 days before blood sampling affected blood mercury levels in both males and females [24]. In line with these results, our study showed that blood mercury levels were significantly higher in the highest seafood consumption quartile than in the lowest seafood consumption quartile in the previous 24 hours. The consumption of fish contaminated with a form of methylmercury is considered to be an important exposure pathway in children and adolescents.

In our study, blood mercury levels were significantly elevated in the overweight male group compared with the levels in the normal group after controlling for covariates, but not in the overweight female group. Possible explanations are that males have more visceral adipose tissue and less subcutaneous adipose tissue than females and that visceral adipose tissue contains higher toxin levels than subcutaneous adipose tissue [25-27]. Our study also showed higher waist circumferences in the overweight male group than in the overweight female group. However, no sex differences were demonstrated in the geometric mean value of blood mercury levels. This finding is consistent with the representative data of blood mercury levels in the Korean general population, which revealed sex differences in blood mercury levels in a population over 20 years old [24]. In rodent studies, sex differences in tissue distribution and clearance of mercury have been demonstrated, and the findings suggest that these differences may be caused by androgens and estrogen $[28,29]$. Our result can be explained by the fact that sex hormones are not as present in participants aged 10-18 years.

Some studies of adults have reported that other factors associated with higher blood mercury levels are household income, alcohol consumption, and smoking $[19,30]$. In our study, blood mercury levels were not significantly associated with household income or the current status of alcohol consumption and smoking after adjustment for covariates. This inconsistency with previous reports could be related to the different definitions of the status of smoking and alcohol consumption, different populations and small numbers of current alcohol consumers and smokers in our study. Hct is also considered to be a covariate related to blood mercury level because up to $80 \%$ of methylmercury binds to red blood cells [10]. Higher blood Hct levels are known to result in greater mercury binding in whole blood and thus a higher mercury concentration in the blood sample [31]. Our results showed that the blood Hct levels in males were higher than those in females, which is related to the report that the differences in hematologic variables between sexes emerge after the onset of menstruation [32]. After adjusting for these possible covariates related to blood mercury levels, our study suggested that blood mercury levels were a significant risk factor for overweight in Korean children and adolescents.

According to the KNHNES 2011-2013, the geometric mean blood mercury level in Korean adults was 3.37 $\mu \mathrm{g} / \mathrm{L}$ [5]. These mercury levels are approximately three to four times higher than those of adults in the U.S. $(0.86 \mu \mathrm{g} / \mathrm{L})$, Germany $(0.58 \mu \mathrm{g} / \mathrm{L})$ or Canada $(0.76 \mu \mathrm{g} / \mathrm{L})[33-35]$. A previous study in a general population noted that as the participants got older, the blood mercury levels increased [24]. Our study, conducted with children and adolescents aged 10-18 years, showed that the geometric means of the blood mercury levels were $2.19 \mu \mathrm{g} / \mathrm{L}, 2.18 \mu \mathrm{g} / \mathrm{L}$, and $2.14 \mu \mathrm{g} / \mathrm{L}$ in all participants, males and females, respectively, after adjusting for covariates. The mercury levels in our study were also much higher than the $0.8 \mu \mathrm{g} / \mathrm{L}$ of the reference value in German children aged 3-14 years old and the $0.3 \mu \mathrm{g} / \mathrm{L}$ of the median blood mercury level in American children and adolescents aged 1-17 years old [36,37]. Accordingly, the blood mercury level in Koreans is greatly higher than that in individuals in Western countries, including children and adolescents. This difference seems to be related to the fact that seafood is a staple food in Korea and can be a primary exposure pathway of methylmercury [38]. In our study, the mean intake of seafood was $54.18 \mathrm{~g} /$ day, which is higher than in Germany (37.5 g/day), Canada (24.7 g/day), and the U.S. (12.8 g/day) [39-41].

Many kinds of fish do not contain high levels of mercury [42]. While balancing concerns for methylmercury exposure, eating a variety of different types of fish is a good way to gain good nutrition because fish contain high-quality protein and omega-3 fatty acids. According to the Environmental Protection Agency (EPA)-FDA advice in the U.S., women of childbearing age (approximately 16-49 years old), pregnant and breastfeeding women, and young children should eat more fish that are low in mercury for important developmental and health benefits [43]. They recommend that those people eat two to three servings (8-12 ounces for adults and children over age 10) of a variety of fish and shellfish each week. Mercury has been widely recognized as a threat to children and adolescents' health, and a global policy for seafood consumption is required to reduce and prevent mercury exposure.

This cross-sectional study has a limitation in that it is difficult to establish accurate cause-effect relationships between overweight and blood mercury levels. To our knowledge, no prospective studies have noted whether overweight/obesity develops or is aggravated after mercury exposure. To understand the underlying pathogenesis of this association between overweight and blood mercury levels, further studies are 
required. Additionally, since environmental conditions are changing, reference values are continuously checked and updated if new information becomes available. Recent national data for mercury exposure in the general population are required.

In conclusion, our study demonstrated an association of mercury exposure with the risk of overweight in Korean children and adolescents. Further studies are needed to investigate the mechanism by which high blood mercury levels are associated with overweight and to establish global guidelines for seafood consumption to reduce mercury exposure in children and adolescents.

\section{Abbreviations}

$\boldsymbol{\beta}$ : regression slope

BMI: body mass index

Cl: confidence interval

KNHANES: Korean National Health and Nutrition Examination Survey

CDC: Centers for Disease Control and Prevention

\section{Declarations}

\section{Ethical Approval and Consent to Participate}

This study was carried out in accordance with the Declaration of Helsinki. The Korean National Health and Nutrition Survey was approved by the Institutional Review Board of the Korean Centers for Disease Control and Prevention (2010-02CON-21-C, 2011-02CON-06-C, 2012-01EXP-012C, and 2013-07CON-03-4C). Written informed consent was obtained from all of the participants and the parents of any participants under the age of 16 years prior to the start of the study.

Consent for publication: Not applicable.

Availability of data and materials: Supporting data can be obtained from the corresponding author.

Competing Interest: The author declares no financial or any other competing interest.

\section{Funding}

The research described in this publication was supported by the Basic Science Research Program through the National Research Foundation of Korea funded by the Ministry of Education (NRF-2018R1D1A1B07046799) and by a Hallym University Research Fund (HURF-2019-42), Anyang si, Korea. The funding bodies had no role in the study design, the collection, analysis or interpretation of the data or the writing of the manuscript.

\section{Author's Contribution}

KYC contributed to the funding acquisition, study design, data analysis, writing an original draft preparation and draft, review, and editing.

\section{Acknowledgments: None}

\section{Author Information}

Department of Pediatrics, Kangnam Sacred Heart Hospital, Hallym University College of Medicine, Seoul, Korea: Ky Young Cho.

Corresponding author: Correspondence to Ky Young Cho.

\section{References}

1. Clauss SB, de Ferranti SD. Update on Preventive Cardiology. Pediatr Clin North Am. 2020;67(5):923-44.

2. Salam RA, Padhani ZA, Das JK, et al. Effects of Lifestyle Modification Interventions to Prevent and Manage Child and Adolescent Obesity: A Systematic Review and Meta-Analysis. Nutrients. 2020;12(8):2208.

3. Stefan N. Causes, consequences, and treatment of metabolically unhealthy fat distribution. Lancet Diabetes Endocrinol. 2020;8(7):616-27. 
4. Jurado-Castro JM, Gil-Campos M, Gonzalez-Gonzalez H, Llorente-Cantarero FJ. Evaluation of Physical Activity and Lifestyle Interventions Focused on School Children with Obesity Using Accelerometry: A Systematic Review and Meta-Analysis. Int J Environ Res Public Health. 2020;17(17):6031.

5. Lee K. Blood mercury concentration in relation to metabolic and weight phenotypes using the KNHANES 2011-2013 data. Int Arch Occup Environ Health. 2018;91(2):185-93.

6. Park JS, Ha KH, He K, Kim DJ. Association between Blood Mercury Level and Visceral Adiposity in Adults. Diabetes Metab J. 2017;41(2):113-20.

7. Eom SY, Choi SH, Ahn SJ, et al. Reference levels of blood mercury and association with metabolic syndrome in Korean adults. Int Arch Occup Environ Health. 2014;87(5):501-13.

8. Kang D-w, Lee K-y. The relationships between blood mercury concentration and body composition measures using 2010 Korean National Health and Nutrition Examination Survey. The Korean Journal of Obesity. 2013;22(4):237-42.

9. Rothenberg SE, Korrick SA, Fayad R. The influence of obesity on blood mercury levels for U.S. non-pregnant adults and children: NHANES 2007-2010. Environmental Research. 2015;138:173-80.

10. Bernhoft RA. Mercury toxicity and treatment: a review of the literature. J Environ Public Health. 2012;2012:460508.

11. Clarkson TW, Magos L. The toxicology of mercury and its chemical compounds. Crit Rev Toxicol. 2006;36(8):609-62.

12. Hong YS, Kim YM, Lee KE. Methylmercury exposure and health effects. J Prev Med Public Health. 2012;45(6):353-63.

13. Ruggieri F, Majorani C, Domanico F, Alimonti A. Mercury in Children: Current State on Exposure through Human Biomonitoring Studies. Int J Environ Res Public Health. 2017;14(5):519.

14. Karagas MR, Choi AL, Oken E, et al. Evidence on the human health effects of low-level methylmercury exposure. Environ Health Perspect. 2012;120(6):799-806.

15. Bose-O'Reilly S, McCarty KM, Steckling N, Lettmeier B. Mercury exposure and children's health. Curr Probl Pediatr Adolesc Health Care. 2010;40(8):186-215.

16. Ha E, Basu N, Bose-O'Reilly S, et al. Current progress on understanding the impact of mercury on human health. Environ Res. 2017;152:419-33.

17. Kweon S, Kim Y, Jang MJ, et al. Data resource profile: the Korea National Health and Nutrition Examination Survey (KNHANES). Int J Epidemiol. 2014;43(1):69-77.

18. Kim JH, Yun S, Hwang SS, et al. The 2017 Korean National Growth Charts for children and adolescents: development, improvement, and prospects. Korean J Pediatr. 2018;61(5):135-49.

19. Lee S, Yoon JH, Won JU, et al. The Association Between Blood Mercury Levels and Risk for Overweight in a General Adult Population: Results from the Korean National Health and Nutrition Examination Survey. Biol Trace Elem Res. 2016;171(2):251-61.

20. Yuk JS, Lee JH, Jeon JD, et al. Menopause and blood mercury levels: the Korea National Health and Nutrition Examination Survey (KNHANES) 2008-2011. Biol Trace Elem Res. 2014;162(1-3):1-7.

21. Shin YY, Ryu IK, Park MJ, Kim SH. The association of total blood mercury levels and overweight among Korean adolescents: analysis of the Korean National Health and Nutrition Examination Survey (KNHANES) 2010-2013. Korean J Pediatr. 2018;61(4):121-8.

22. Taylor CM, Emmett PM, Emond AM, Golding J. A review of guidance on fish consumption in pregnancy: is it fit for purpose? Public Health Nutr. 2018;21(11):2149-59.

23. Branco V, Caito S, Farina M, et al. Biomarkers of mercury toxicity: Past, present, and future trends. J Toxicol Environ Health B Crit Rev. 2017;20(3):119-54.

24. Eom SY, Lee YS, Lee SG, et al. Lead, Mercury, and Cadmium Exposure in the Korean General Population. J Korean Med Sci. $2018 ; 33(2):$ e9.

25. White UA, Tchoukalova YD. Sex dimorphism and depot differences in adipose tissue function. Biochim Biophys Acta. 2014;1842(3):37792.

26. Chang E, Varghese M, Singer K. Gender and Sex Differences in Adipose Tissue. Curr Diab Rep. 2018;18(9):69.

27. Jackson E, Shoemaker R, Larian N, Cassis L. Adipose Tissue as a Site of Toxin Accumulation. Compr Physiol. 2017;7(4):1085-135.

28. Hazelhoff MH, Bulacio RP, Torres AM. Gender related differences in kidney injury induced by mercury. Int J Mol Sci. 2012;13(8):10523-36.

29. Thomas DJ, Fisher HL, Sumler MR, et al. Sexual differences in the distribution and retention of organic and inorganic mercury in methyl mercury-treated rats. Environmental research. 1986;41(1):219-34.

30. Fresquez MR, Gonzalez-Jimenez N, Gray N, Watson CH, Pappas RS. High-Throughput Determination of Mercury in Tobacco and Mainstream Smoke from Little Cigars. J Anal Toxicol. 2015;39(7):545-50.

31. Kim B-M, Choi AL, Ha E-H, et al. Effect of hemoglobin adjustment on the precision of mercury concentrations in maternal and cord blood. Environmental research. 2014;132:407-12. 
32. Pluncevic Gligoroska J, Gontarev S, Dejanova B, et al. Red Blood Cell Variables in Children and Adolescents regarding the Age and Sex. Iran J Public Health. 2019;48(4):704-12.

33. Control CfD, Prevention. Fourth report on human exposure to environmental chemicals, updated tables. US Department of Health and Human Services, Centers for Disease Control and Prevention. 2017.

34. Becker K, Kaus S, Krause C, et al. German Environmental Survey 1998 (GerES III): environmental pollutants in blood of the German population. Int J Hyg Environ Health. 2002;205(4):297-308.

35. Wong SL, Lye EJ. Lead, mercury and cadmium levels in Canadians. Health Reports. 2008;19(4):31.

36. Schulz C, Angerer J, Ewers U, Heudorf U, Wilhelm M. Revised and new reference values for environmental pollutants in urine or blood of children in Germany derived from the German environmental survey on children 2003-2006 (GerES IV). Int J Hyg Environ Health. 2009;212(6):637-47.

37. Control CfD, Prevention. Fourth national report on human exposure to environmental chemicals: Updated tables, January 2017, volume one. US Department of Health and Human Services, Centers for Disease Control and Prevention (CDC): Atlanta, GA[Google Scholar]. 2017.

38. Supartini A, Oishi T, Yagi N. Changes in Fish Consumption Desire and Its Factors: A Comparison between the United Kingdom and Singapore. Foods. 2018;7(7):97.

39. Agency USEP. Intake of Fish and Shellfish. In: Exposure factors handbook 2011 edition (Final report). https://www.epa.gov/sites/production/files/2015-09/documents/efh-chapter10.pdf (2011). Accessed Sep 2011.

40. Koptyug E. Per capita consumption of fish and fishery products in Germany from 1980 to 2018. https://www.statista.com/statistics/539983/fish-per-capita-consumption-in-germany/\#statisticContainer (2019). Accessed Oct 2019.

41. Canada. AaA-f. Per capita disappearance: Protein disappearnce of animal protein sources in Canada (food available per persion, per year). https://www.agr.gc.ca/eng/animal-industry/poultry-and-egg-market-information/industry-indicators/per-capita-disappearance/? id=1384971854413 (2020). Accessed Aug 2020.

42. Swanson D, Block R, Mousa SA. Omega-3 fatty acids EPA and DHA: health benefits throughout life. Adv Nutr. 2012;3(1):1-7.

43. Hegstad M. New Peer Review Further Delays Final Joint EPA-FDA Fish Advisory. Inside EPA's Risk Policy Report. 2016;23(34):1-5.

\section{Tables}




\begin{tabular}{|c|c|c|c|c|c|c|c|c|c|}
\hline & \multicolumn{3}{|l|}{ All $(n=1327)$} & \multicolumn{3}{|l|}{ Male $(n=672)$} & \multicolumn{3}{|c|}{ Female $(n=655)$} \\
\hline & $\begin{array}{l}\text { Normal } \\
(n=1060)\end{array}$ & $\begin{array}{l}\text { Overweight } \\
(n=267)\end{array}$ & $\begin{array}{l}P \\
\text { value }\end{array}$ & $\begin{array}{l}\text { Normal } \\
(n=529)\end{array}$ & $\begin{array}{l}\text { Overweight } \\
(n=143)\end{array}$ & $\begin{array}{l}P \\
\text { value }\end{array}$ & $\begin{array}{l}\text { Normal } \\
(n=531)\end{array}$ & $\begin{array}{l}\text { Overweight } \\
(\mathrm{n}=124)\end{array}$ & $\begin{array}{l}P \\
\text { value }\end{array}$ \\
\hline Age (yr) & $14.33 \pm 0.09$ & $14.19 \pm 0.18$ & 0.482 & $14.37 \pm 0.13$ & $14.02 \pm 0.25$ & 0.204 & $14.29 \pm 0.14$ & $14.40 \pm 0.27$ & 0.712 \\
\hline Age group & & & 0.550 & & & 0.303 & & & \\
\hline $10-12 y r$ & $360(27.8)$ & $93(28.3)$ & & $182(27.6)$ & $53(31.3)$ & & $178(28.1)$ & $40(24.6)$ & 0.801 \\
\hline $13-15 y r$ & $380(34.3)$ & $96(37.8)$ & & $194(34.3)$ & $50(38.7)$ & & $186(34.3)$ & $46(36.6)$ & \\
\hline $16-18 y r$ & 320 (37.9) & 78 (33.9) & & $153(38.1)$ & $40(29.9)$ & & 167 (37.6) & $38(38.8)$ & \\
\hline Year & & & 0.488 & & & 0.552 & & & 0.548 \\
\hline 2010 & $266(25.8)$ & $71(24.1)$ & & $125(24.9)$ & $43(26.7)$ & & $141(26.8)$ & $28(21.0)$ & \\
\hline 2011 & $266(26.1)$ & $72(28.7)$ & & $140(26.9)$ & $33(26.4)$ & & $126(25.2)$ & 39 (31.5) & \\
\hline 2012 & $277(24.8)$ & $50(20.4)$ & & $141(25.7)$ & 27 (19.4) & & $136(23.8)$ & $23(21.5)$ & \\
\hline 2013 & $251(23.3)$ & $74(26.8)$ & & $123(22.6)$ & $40(27.4)$ & & $128(24.2)$ & $34(26.0)$ & \\
\hline Weight (kg) & $51.81 \pm 0.37$ & $70.77 \pm 0.98$ & $0.000^{*}$ & $54.53 \pm 0.58$ & $75.17 \pm 1.54$ & $0.000^{*}$ & $48.80 \pm 0.40$ & $65.39 \pm 0.98$ & $0.000^{*}$ \\
\hline Height $(\mathrm{cm})$ & $161.88 \pm 0.39$ & $163.54 \pm 0.71$ & 0.046 & $165.58 \pm 0.63$ & $166.78 \pm 1.09$ & 0.343 & $157.78 \pm 0.38$ & $159.59 \pm 0.75$ & 0.033 \\
\hline BMI $\left(\mathrm{kg} / \mathrm{m}^{2}\right)$ & $19.58 \pm 0.08$ & $26.19 \pm 0.21$ & $0.000^{*}$ & $19.66 \pm 0.12$ & $26.69 \pm 0.26$ & $0.000^{*}$ & $19.48 \pm 0.10$ & $25.60 \pm 0.34$ & $0.000^{*}$ \\
\hline WC $(\mathrm{cm})$ & $66.50 \pm 0.08$ & $82.19 \pm 0.59$ & $0.000^{*}$ & $67.78 \pm 0.35$ & $85.38 \pm 0.84$ & $0.000^{*}$ & $65.08 \pm 0.31$ & $78.28 \pm 0.73$ & $0.000^{*}$ \\
\hline $\begin{array}{l}\text { Mercury } \\
(\mu \mathrm{g} / \mathrm{L})\end{array}$ & $2.09 \pm 0.04$ & $2.43 \pm 0.08$ & $0.000^{*}$ & $2.13 \pm 0.05$ & $2.46 \pm 0.10$ & $0.005^{\star}$ & $2.05 \pm 0.06$ & $2.39 \pm 0.11$ & $0.010^{\star}$ \\
\hline Hct (\%) & $41.66 \pm 0.12$ & $41.93 \pm 0.23$ & 0.302 & $43.28 \pm 0.16$ & $43.49 \pm 0.33$ & 0.546 & $39.87 \pm 0.14$ & $40.01 \pm 0.21$ & 0.559 \\
\hline $\begin{array}{l}\text { Seafood } \\
\text { consumption } \\
\text { in the } \\
\text { previous } 24 \\
\text { hours } \\
\text { (g/day) }\end{array}$ & $54.18 \pm 3.27$ & $59.31 \pm 5.69$ & 0.435 & $63.67 \pm 5.49$ & $52.76 \pm 6.86$ & 0.217 & $43.68 \pm 3.16$ & $67.68 \pm 9.35$ & $0.015^{\star}$ \\
\hline $\begin{array}{l}\text { Household } \\
\text { Income }\end{array}$ & & & 0.420 & & & 0.150 & & & 0.215 \\
\hline Quartile 1 & $126(14.6)$ & $29(12.7)$ & & $61(15.0)$ & $12(11.0)$ & & $65(14.1)$ & $17(14.8)$ & \\
\hline Quartile 2 & $274(29.9)$ & $82(34.1)$ & & $137(30.6)$ & $37(29.3)$ & & 137 (29.2) & 45 (39.7) & \\
\hline Quartile 3 & $342(29.5)$ & $71(24.5)$ & & $172(28.4)$ & 35 (22.3) & & $170(30.7)$ & $36(27.1)$ & \\
\hline Quartile 4 & $311(26.0)$ & $83(28.7)$ & & $156(26.1)$ & 57 (37.4) & & $155(26.0)$ & 26 (18.3) & \\
\hline $\begin{array}{l}\text { Consuming } \\
\text { alcohol more } \\
\text { than once in } \\
\text { the last } \\
\text { month }\end{array}$ & & & 0.320 & & & 0.569 & & & 0.402 \\
\hline No & $1012(95.3)$ & $253(93.1)$ & & $504(94.0)$ & $133(92.3)$ & & $508(96.8)$ & $120(79.3)$ & \\
\hline Yes & $39(4.7)$ & $11(6.9)$ & & $22(6.0)$ & $9(7.7)$ & & $17(3.2)$ & $2(6.0)$ & \\
\hline $\begin{array}{l}\text { Smoking } \\
\text { more than } \\
\text { once in the } \\
\text { last month }\end{array}$ & & & 0.382 & & & 0.680 & & & 0.384 \\
\hline No & 979 (93.7) & $239(91.8)$ & & 478 (91.1) & 124 (89.7) & & $501(96.7)$ & $115(94.4)$ & \\
\hline Yes & $50(6.3)$ & 18 (8.2) & & $35(8.9)$ & 12 (10.3) & & 15 (3.3) & $6(5.6)$ & \\
\hline
\end{tabular}


Page 10/16 


\begin{tabular}{|c|c|c|c|c|c|c|c|c|c|}
\hline & \multicolumn{3}{|l|}{ All } & \multicolumn{3}{|c|}{ Male } & \multicolumn{3}{|c|}{ Female } \\
\hline & $\mathrm{N}$ & Crude & $\begin{array}{l}\text { Adjusted } \\
(n=1096)\end{array}$ & $\mathrm{N}$ & Crude & $\begin{array}{l}\text { Adjusted } \\
(n=553)\end{array}$ & $\mathrm{N}$ & Crude & $\begin{array}{l}\text { Adjusted } \\
(n=543)\end{array}$ \\
\hline All & 1327 & $\begin{array}{l}2.16 \\
(2.09- \\
2.24)\end{array}$ & $\begin{array}{l}2.19(2.06- \\
2.26)\end{array}$ & 672 & $\begin{array}{l}2.13 \\
(2.02- \\
2.24)\end{array}$ & $\begin{array}{l}2.18 \\
(1.98- \\
2.38)\end{array}$ & 655 & $\begin{array}{l}2.05 \\
(1.92- \\
2.17)\end{array}$ & $\begin{array}{l}2.14 \\
(1.91- \\
2.36)\end{array}$ \\
\hline Age Group & 1327 & & & 672 & & & 655 & & \\
\hline $10-12 \mathrm{yr}$ & & $\begin{array}{l}2.09 \\
(1.99- \\
2.19)\end{array}$ & $\begin{array}{l}2.31(1.95- \\
2.67)\end{array}$ & & $\begin{array}{l}2.09 \\
(1.95- \\
2.24)\end{array}$ & $\begin{array}{l}2.39 \\
(1.96- \\
2.82)\end{array}$ & & $\begin{array}{l}2.08 \\
(1.96- \\
2.20)\end{array}$ & $\begin{array}{l}2.21 \\
(1.58- \\
2.84)\end{array}$ \\
\hline $13-15 \mathrm{yr}$ & & $\begin{array}{l}2.23 \\
(2.11- \\
2.36)\end{array}$ & $\begin{array}{l}2.27(2.03- \\
2.52)\end{array}$ & & $\begin{array}{l}2.33 \\
(2.16- \\
2.50)\end{array}$ & $\begin{array}{l}2.30 \\
(2.08- \\
2.53)\end{array}$ & & $\begin{array}{l}2.12 \\
(1.96- \\
2.28)\end{array}$ & $\begin{array}{l}2.17 \\
(1.69- \\
2.66)\end{array}$ \\
\hline $16-18 \mathrm{yr}$ & & $\begin{array}{l}2.15 \\
(2.02- \\
2.28)\end{array}$ & $\begin{array}{l}1.96(1.59- \\
2.33)\end{array}$ & & $\begin{array}{l}2.16 \\
(2.02- \\
2.31)\end{array}$ & $\begin{array}{l}1.73 \\
(1.31- \\
2.16)\end{array}$ & & $\begin{array}{l}2.14 \\
(1.92- \\
2.36)\end{array}$ & $\begin{array}{l}2.25 \\
(1.66- \\
2.84)\end{array}$ \\
\hline Overweight Group & 1327 & & & 672 & & & 655 & & \\
\hline Normal & & $\begin{array}{l}2.09 \\
(2.01- \\
2.17)\end{array}$ & $\begin{array}{l}2.07(1.89- \\
2.26)\end{array}$ & & $\begin{array}{l}2.13 \\
(2.02- \\
2.24)\end{array}$ & $\begin{array}{l}2.06 \\
(1.87- \\
2.25)\end{array}$ & & $\begin{array}{l}2.05 \\
(1.92- \\
2.17)\end{array}$ & $\begin{array}{l}2.15 \\
(1.77- \\
2.53)\end{array}$ \\
\hline Overweight & & $\begin{array}{l}2.43 \\
(2.28- \\
2.58)^{* *}\end{array}$ & $\begin{array}{l}2.34(2.08- \\
2.59)^{* *}\end{array}$ & & $\begin{array}{l}2.36 \\
(2.25- \\
2.66)^{* *}\end{array}$ & $\begin{array}{l}2.31 \\
(2.04- \\
2.58)^{*}\end{array}$ & & $\begin{array}{l}2.39 \\
(2.17- \\
2.62)^{\text {** }}\end{array}$ & $\begin{array}{l}2.35 \\
(1.90- \\
2.81)\end{array}$ \\
\hline Hematocrit & 1327 & & & 672 & & & 655 & & \\
\hline Quartile 1 & & $\begin{array}{l}1.99 \\
(1.86- \\
2.14)\end{array}$ & $\begin{array}{l}1.98(1.74- \\
2.22)\end{array}$ & & $\begin{array}{l}1.85 \\
(1.67- \\
2.03)\end{array}$ & $\begin{array}{l}1.73 \\
(1.45- \\
2.01)\end{array}$ & & $\begin{array}{l}2.04 \\
(1.87- \\
2.21)\end{array}$ & $\begin{array}{l}2.13 \\
(1.71- \\
2.55)\end{array}$ \\
\hline Quartile 2 & & $\begin{array}{l}2.15 \\
(2.02- \\
2.28)\end{array}$ & $\begin{array}{l}2.14(1.88- \\
2.39)\end{array}$ & & $\begin{array}{l}2.14 \\
(1.93- \\
2.34)^{*}\end{array}$ & $\begin{array}{l}1.97 \\
(1.69- \\
2.24)\end{array}$ & & $\begin{array}{l}2.16 \\
(1.99- \\
2.33)\end{array}$ & $\begin{array}{l}2.31 \\
(1.85- \\
2.76)\end{array}$ \\
\hline Quartile 3 & & $\begin{array}{l}2.22 \\
(2.09- \\
2.34)^{*}\end{array}$ & $\begin{array}{l}2.25(2.01- \\
2.49)^{*}\end{array}$ & & $\begin{array}{l}2.25 \\
(2.09- \\
2.41)^{\text {** }}\end{array}$ & $\begin{array}{l}2.24 \\
(1.99- \\
2.49)^{* *}\end{array}$ & & $\begin{array}{l}2.17 \\
(1.96- \\
2.38)\end{array}$ & $\begin{array}{l}2.28 \\
(1.84- \\
2.73)\end{array}$ \\
\hline Quartile 4 & & $\begin{array}{l}2.27 \\
(2.13- \\
2.41)^{\text {** }}\end{array}$ & $\begin{array}{l}2.24(1.99- \\
2.45)^{\star}\end{array}$ & & $\begin{array}{l}2.28 \\
(2.13- \\
2.43)^{* *}\end{array}$ & $\begin{array}{l}2.21 \\
(1.98- \\
2.45)^{* k}\end{array}$ & & $\begin{array}{l}2.16 \\
(1.77- \\
2.54)\end{array}$ & $\begin{array}{l}2.37 \\
(1.77- \\
2.97)\end{array}$ \\
\hline Household Income & 1318 & & & 667 & & & 651 & & \\
\hline Quartile 1 & & $\begin{array}{l}2.12 \\
(1.97- \\
2.27)\end{array}$ & $\begin{array}{l}2.11(1.86- \\
2.35)\end{array}$ & & $\begin{array}{l}2.11 \\
(1.90- \\
2.31)\end{array}$ & $\begin{array}{l}2.08 \\
(1.83- \\
2.34)\end{array}$ & & $\begin{array}{l}2.13 \\
(1.92- \\
2.36)\end{array}$ & $\begin{array}{l}2.20 \\
(1.73- \\
2.67)\end{array}$ \\
\hline Quartile 2 & & $\begin{array}{l}2.03 \\
(1.91- \\
2.15)\end{array}$ & $\begin{array}{l}2.01 \\
2.25)\end{array}$ & & $\begin{array}{l}1.98 \\
(1.84- \\
2.11)\end{array}$ & $\begin{array}{l}1.92 \\
(1.70- \\
2.13)\end{array}$ & & $\begin{array}{l}2.09 \\
(1.89- \\
2.28)\end{array}$ & $\begin{array}{l}2.17 \\
(1.72- \\
2.62)\end{array}$ \\
\hline Quartile 3 & & $\begin{array}{l}2.16 \\
(2.04- \\
2.28)\end{array}$ & $\begin{array}{l}2.12(1.88- \\
2.35)\end{array}$ & & $\begin{array}{l}2.24 \\
(2.07- \\
2.41)\end{array}$ & $\begin{array}{l}2.14 \\
(1.88- \\
2.39)\end{array}$ & & $\begin{array}{l}2.07 \\
(1.91- \\
2.23)\end{array}$ & $\begin{array}{l}2.16 \\
(1.73- \\
2.59)\end{array}$ \\
\hline Quartile 4 & & $\begin{array}{l}2.35 \\
(2.19- \\
2.52)^{*}\end{array}$ & $\begin{array}{l}2.34(2.06- \\
2.61)\end{array}$ & & $\begin{array}{l}2.46 \\
(2.23- \\
2.68)^{*}\end{array}$ & $\begin{array}{l}2.34 \\
(2.05- \\
2.63)\end{array}$ & & $\begin{array}{l}2.21 \\
(1.96- \\
2.47)\end{array}$ & $\begin{array}{l}2.34 \\
(1.86- \\
2.83)\end{array}$ \\
\hline Seafood Consumption & 1137 & & & 576 & & & 561 & & \\
\hline Quartile 1 & & $\begin{array}{l}1.99 \\
(1.87- \\
2.13)\end{array}$ & $\begin{array}{l}1.98(1.77- \\
2.20)\end{array}$ & & $\begin{array}{l}2.09 \\
(1.91- \\
2.27)\end{array}$ & $\begin{array}{l}2.02 \\
(1.78- \\
2.26)\end{array}$ & & $\begin{array}{l}1.91 \\
(1.71- \\
2.10)\end{array}$ & $\begin{array}{l}1.96 \\
(1.55- \\
2.38)\end{array}$ \\
\hline
\end{tabular}

Page $11 / 16$ 


\begin{tabular}{|c|c|c|c|c|c|c|c|}
\hline Quartile 2 & & $\begin{array}{l}2.13 \\
(1.97- \\
2.29)\end{array}$ & $\begin{array}{l}2.10(1.85- \\
2.36)\end{array}$ & $\begin{array}{l}2.15 \\
(1.94- \\
2.37)\end{array}$ & $\begin{array}{l}2.04 \\
(1.77- \\
2.31)\end{array}$ & $\begin{array}{l}2.10 \\
(1.85- \\
2.26)\end{array}$ & $\begin{array}{l}2.18 \\
(1.72- \\
2.64)\end{array}$ \\
\hline Quartile 3 & & $\begin{array}{l}2.19 \\
(2.06- \\
2.32)^{*}\end{array}$ & $\begin{array}{l}2.14(1.90- \\
2.37)\end{array}$ & $\begin{array}{l}2.26 \\
(2.04- \\
2.47)\end{array}$ & $\begin{array}{l}2.10 \\
(1.84- \\
2.37)\end{array}$ & $\begin{array}{l}2.13 \\
(1.97- \\
2.29)\end{array}$ & $\begin{array}{l}2.21 \\
(1.77- \\
2.64)^{*}\end{array}$ \\
\hline Quartile 4 & & $\begin{array}{l}2.38 \\
(2.22- \\
2.54)^{\star \star}\end{array}$ & $\begin{array}{l}2.33(2.04- \\
2.61)^{*}\end{array}$ & $\begin{array}{l}2.34 \\
(2.17- \\
2.51)^{*}\end{array}$ & $\begin{array}{l}2.29 \\
(2.05- \\
2.53)^{*}\end{array}$ & $\begin{array}{l}2.44 \\
(2.13- \\
2.75)^{\star \star}\end{array}$ & $\begin{array}{l}2.49 \\
(2.02- \\
2.96)^{\star *}\end{array}$ \\
\hline $\begin{array}{l}\text { Consuming alcohol more than once } \\
\text { in the last month }\end{array}$ & 1315 & & & & & & \\
\hline No & & $\begin{array}{l}2.16 \\
(2.09- \\
2.24)\end{array}$ & $\begin{array}{l}2.19(2.04- \\
2.33)\end{array}$ & $\begin{array}{l}2.21 \\
(2.11- \\
2.31)\end{array}$ & $\begin{array}{l}2.21 \\
(2.06- \\
2.36)\end{array}$ & $\begin{array}{l}2.12 \\
(2.01- \\
2.23)\end{array}$ & $\begin{array}{l}2.22 \\
(1.87- \\
2.56)\end{array}$ \\
\hline Yes & & $\begin{array}{l}2.17 \\
(1.92- \\
2.42)\end{array}$ & $\begin{array}{l}2.09 \\
2.45)\end{array}$ & $\begin{array}{l}2.15 \\
(1.92- \\
2.38)\end{array}$ & $\begin{array}{l}2.03 \\
(1.72- \\
2.34)\end{array}$ & $\begin{array}{l}2.20 \\
(1.63- \\
2.77)\end{array}$ & $\begin{array}{l}2.23 \\
(1.56- \\
2.89)\end{array}$ \\
\hline Smoking during the last month & 1021 & & & & & & \\
\hline No & & $\begin{array}{l}2.17 \\
(2.09- \\
2.24)\end{array}$ & $\begin{array}{l}2.16(1.99- \\
2.32)\end{array}$ & $\begin{array}{l}2.21 \\
(2.10- \\
2.31)\end{array}$ & $\begin{array}{l}2.15 \\
(1.99- \\
2.30)\end{array}$ & $\begin{array}{l}2.13 \\
(2.02- \\
2.24)\end{array}$ & $\begin{array}{l}2.16 \\
(1.85- \\
2.48)\end{array}$ \\
\hline Yes & & $\begin{array}{l}2.13 \\
(1.91- \\
2.35)\end{array}$ & $\begin{array}{l}2.13(1.81- \\
2.45)\end{array}$ & $\begin{array}{l}2.15 \\
(1.95- \\
2.36)\end{array}$ & $\begin{array}{l}2.09 \\
(1.80- \\
2.39)\end{array}$ & $\begin{array}{l}2.06 \\
(.146- \\
2.66)\end{array}$ & $\begin{array}{l}2.28 \\
(1.59- \\
2.97)\end{array}$ \\
\hline
\end{tabular}

Table 3. Regression coefficient $(\beta)$ and $95 \%$ confidence intervals for logarithmically transformed body mass index associated with logarithmically transformed blood mercury concentrations, stratified by age and sex.

\begin{tabular}{|c|c|c|c|c|c|c|c|c|c|}
\hline & $\mathrm{N}$ & All $(n=1327)$ & $P$ value & $\mathrm{N}$ & Male $(n=672)$ & $P$ value & $\mathrm{N}$ & Female $(n=655)$ & $P$ value \\
\hline Model 1 & 1327 & $0.053(0.030-0.075)$ & 0.000 & 672 & $0.049(0.017-0.082)$ & 0.003 & 655 & $0.055(0.025-0.085)$ & 0.000 \\
\hline Model 2 & 1327 & $0.050(0.028-0.072)$ & 0.000 & 672 & $0.044(0.012-0.076)$ & 0.007 & 655 & $0.058(0.029-0.087)$ & 0.000 \\
\hline Model 3 & 1137 & $0.032(0.010-0.054)$ & 0.004 & 576 & $0.026(0.010-0.023)$ & 0.106 & 561 & $0.038(0.006-0.070)$ & 0.022 \\
\hline Model 4 & 1096 & $0.034(0.011-0.057)$ & 0.003 & 553 & $0.030(-0.003-0.063)$ & 0.071 & 543 & $0.038(0.005-0.070)$ & 0.024 \\
\hline Model 5 & 1096 & $0.033(0.009-0.056)$ & 0.006 & 553 & $0.026(-0.007-0.059)$ & 0.123 & 543 & $0.036(0.004-0.069)$ & 0.027 \\
\hline
\end{tabular}




\begin{tabular}{|c|c|c|c|c|c|c|c|}
\hline & & All $(n=1327)$ & $P$ value for trend & Male $(n=672)$ & $P$ value for trend & Female $(n=672)$ & $P$ value for trend \\
\hline \multirow[t]{4}{*}{ Crude } & Q1 & Reference & 0.000 & Reference & 0.018 & Reference & 0.016 \\
\hline & Q2 & $0.85(0.52-1.38)$ & & $1.16(0.61-2.22)$ & & $0.55(0.26-1.17)$ & \\
\hline & Q3 & $0.94(0.59-1.48)$ & & $0.81(0.42-1.56)$ & & $1.30(0.69-2.46)$ & \\
\hline & Q4 & $2.15(1.36-3.41)$ & & $1.99(1.06-3.62)$ & & $1.87(0.98-3.58)$ & \\
\hline \multirow[t]{4}{*}{ Model 1} & Q1 & Reference & 0.000 & Reference & 0.015 & Reference & 0.015 \\
\hline & Q2 & $0.86(0.53-1.39)$ & & $1.20(0.53-2.31)$ & & $0.56(0.26-1.20)$ & \\
\hline & Q3 & $1.10(0.69-1.74)$ & & $0.84(0.44-1.63)$ & & $1.32(0.69-2.51)$ & \\
\hline & Q4 & $2.15(1.36-3.42)$ & & $2.05(1.09-3.82)$ & & $1.89(0.98-3.63)$ & \\
\hline \multirow[t]{4}{*}{ Model 2} & Q1 & Reference & 0.004 & Reference & 0.055 & Reference & 0.020 \\
\hline & Q2 & $0.86(0.49-1.32)$ & & $1.32(0.65-2.67)$ & & $0.52(0.24-1.11)$ & \\
\hline & Q3 & $0.81(0.49-1.32)$ & & $0.83(0.41-1.67)$ & & $1.29(0.67-2.49)$ & \\
\hline & Q4 & $1.76(1.01-2.87)$ & & $1.87(0.93-3.73)$ & & $1.81(0.93-3.51)$ & \\
\hline \multirow[t]{4}{*}{ Model 3} & Q1 & Reference & 0.003 & Reference & 0.024 & Reference & 0.032 \\
\hline & Q2 & $0.88(0.48-1.30)$ & & $1.51(0.74-3.11)$ & & $0.47(0.19-1.12)$ & \\
\hline & Q3 & $0.79(0.48-1.30)$ & & $0.83(0.41-1.71)$ & & $1.28(0.62-2.65)$ & \\
\hline & Q4 & $1.80(1.10-2.96)$ & & $2.11(1.03-4.33)$ & & $1.85(0.89-3.79)$ & \\
\hline \multirow[t]{4}{*}{ Model 4} & Q1 & Reference & 0.005 & Reference & 0.024 & Reference & 0.038 \\
\hline & Q2 & $0.88(0.52-1.48)$ & & $1.58(0.77-3.24)$ & & $0.49(0.23-1.08)$ & \\
\hline & Q3 & $0.79(0.47-1.30)$ & & $0.82(0.39-1.69)$ & & $0.85(0.41-1.77)$ & \\
\hline & Q4 & $1.78(1.06-2.98)$ & & $2.06(1.01-4.23)$ & & $1.52(0.74-3.12)$ & \\
\hline
\end{tabular}




\begin{tabular}{|c|c|c|c|c|c|c|}
\hline & & Quartile 1 & Quartile 2 & Quartile 3 & Quartile 4 & $P$ value \\
\hline All & $\mathrm{Hg}(\mu \mathrm{g} / \mathrm{dL})$ & $1.11(1.08-1.14)$ & $1.63(1.62-1.65)$ & $2.16(2.14-2.19)$ & $3.54(3.39-3.67)$ & 0.000 \\
\hline \multirow[t]{3}{*}{$(n=1327)$} & Overweight Group & $(n=332)$ & $(n=329)$ & $(n=338)$ & $(n=328)$ & 0.000 \\
\hline & Normal & $279(82.0)$ & $278(84.3)$ & $273(82.9)$ & $230(67.9)$ & \\
\hline & Overweight & $53(18.0)$ & $51(15.7)$ & $65(17.1)$ & $98(32.1)$ & \\
\hline Male & $\mathrm{Hg}(\mu \mathrm{g} / \mathrm{dL})$ & $1.10(1.06-1.15)$ & $1.65(1.63-1.67)$ & $2.19(2.16-2.22)$ & $3.57(3.42-3.73)$ & 0.000 \\
\hline \multirow[t]{3}{*}{$(n=672)$} & Overweight Group & $(n=164)$ & $(n=156)$ & $(n=176)$ & $(n=176)$ & 0.017 \\
\hline & Normal & $141(81.4)$ & $125(79.0)$ & $141(84.3)$ & $122(69.0)$ & \\
\hline & Overweight & $23(18.6)$ & $31(21.0)$ & $35(15.7)$ & $54(31.0)$ & \\
\hline Female & $\mathrm{Hg}(\mu \mathrm{g} / \mathrm{dL})$ & $1.12(1.08-1.16)$ & $1.62(1.59-1.64)$ & $2.14(2.10-2.17)$ & $3.49(3.28-3.71)$ & 0.000 \\
\hline \multirow[t]{3}{*}{$(n=655)$} & Overweight Group & $(n=168)$ & $(n=173)$ & $(n=162)$ & $(n=152)$ & 0.000 \\
\hline & Normal & $138(82.6)$ & $153(90.2)$ & $132(81.1)$ & $108(66.5)$ & \\
\hline & Overweight & $30(17.4)$ & $20(9.8)$ & $30(18.9)$ & $44(33.5)$ & \\
\hline
\end{tabular}

\section{Figures}

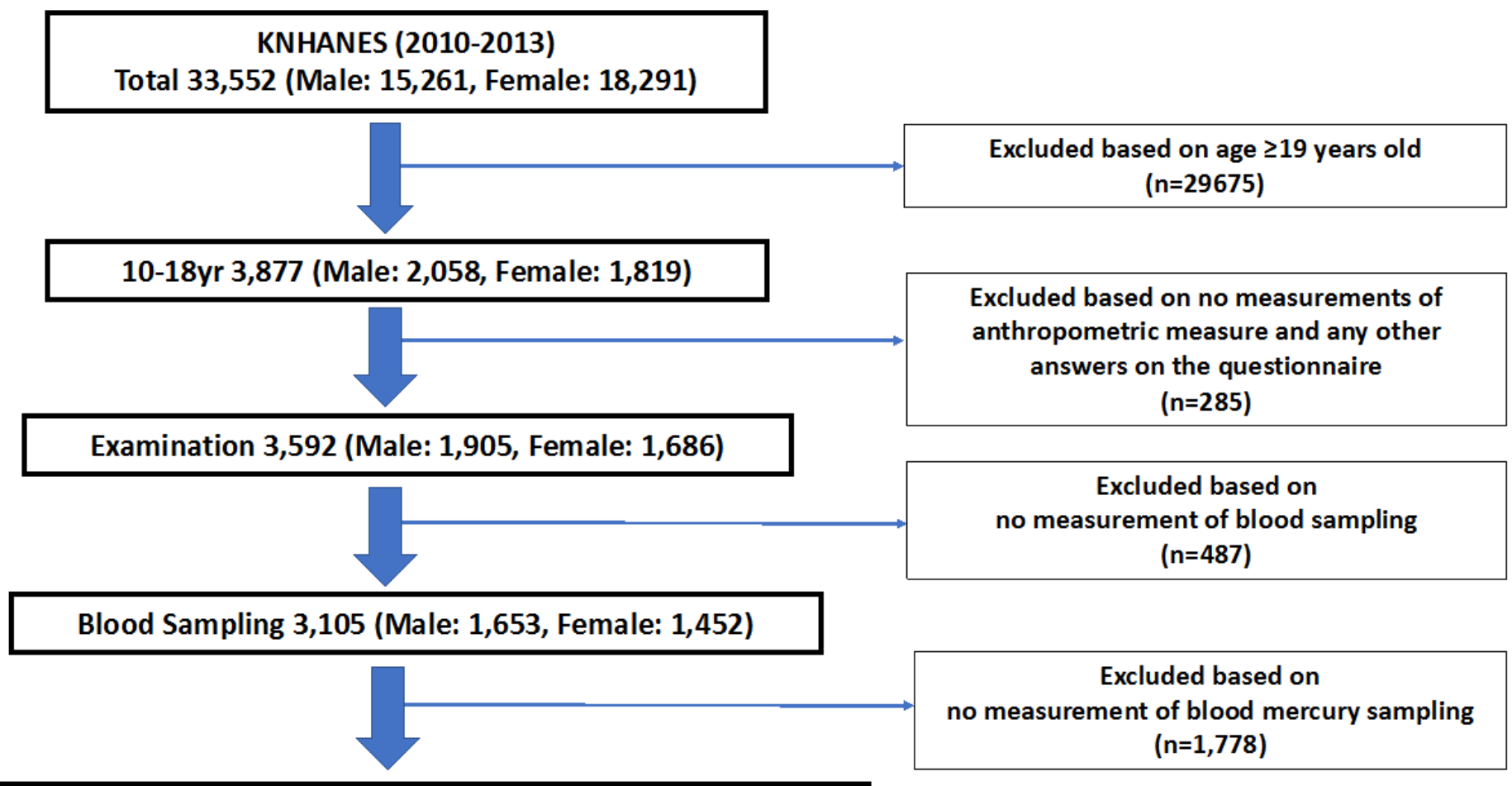

\section{Blood Mercury Sampling 1,327 (Male: 672, Female: 655)}

Figure 1

The study participant exclusion and inclusion criteria. 


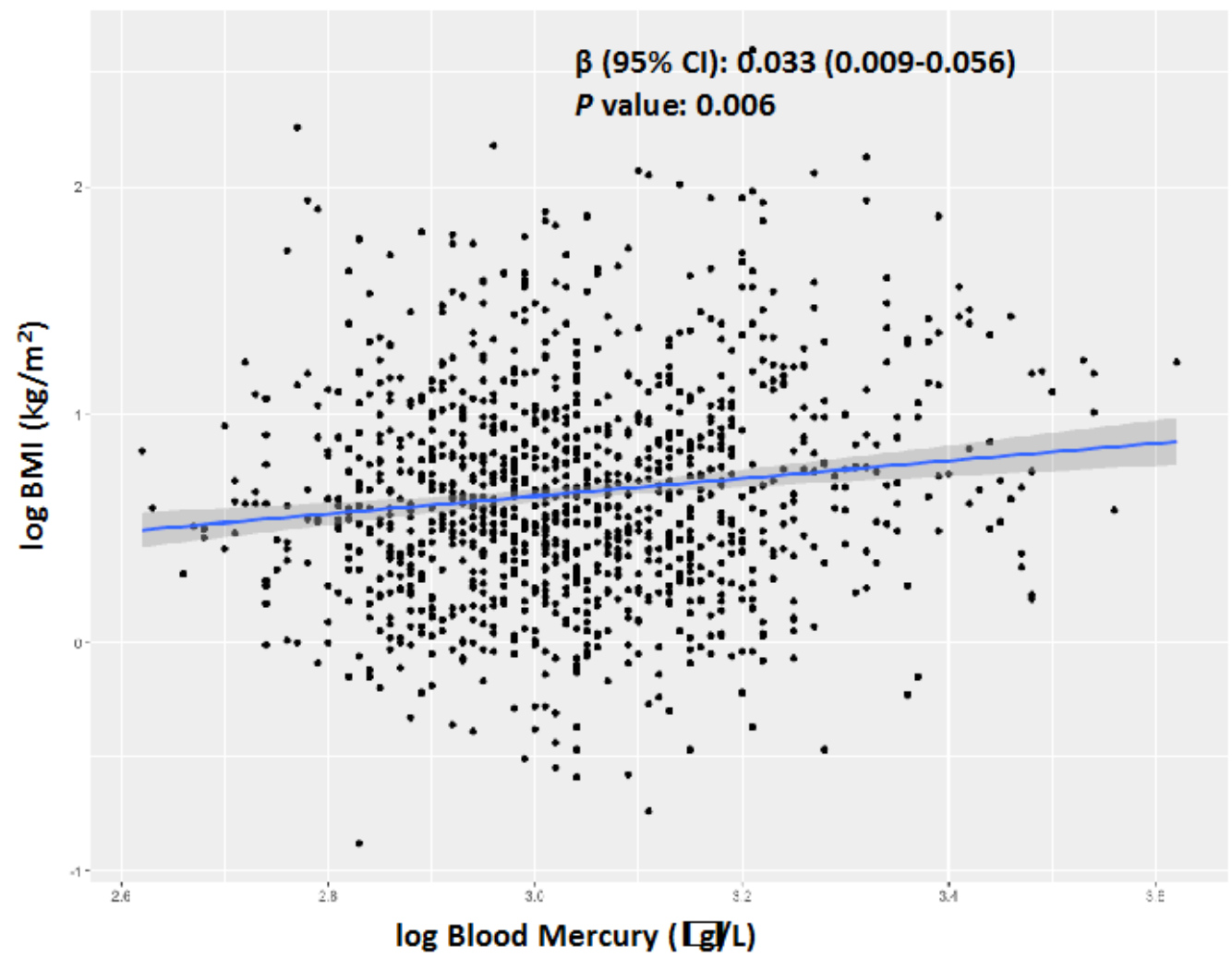

Figure 2

The scatter plot shows the positive association between logarithmically transformed BMI and logarithmically transformed blood mercury levels in all participants. 


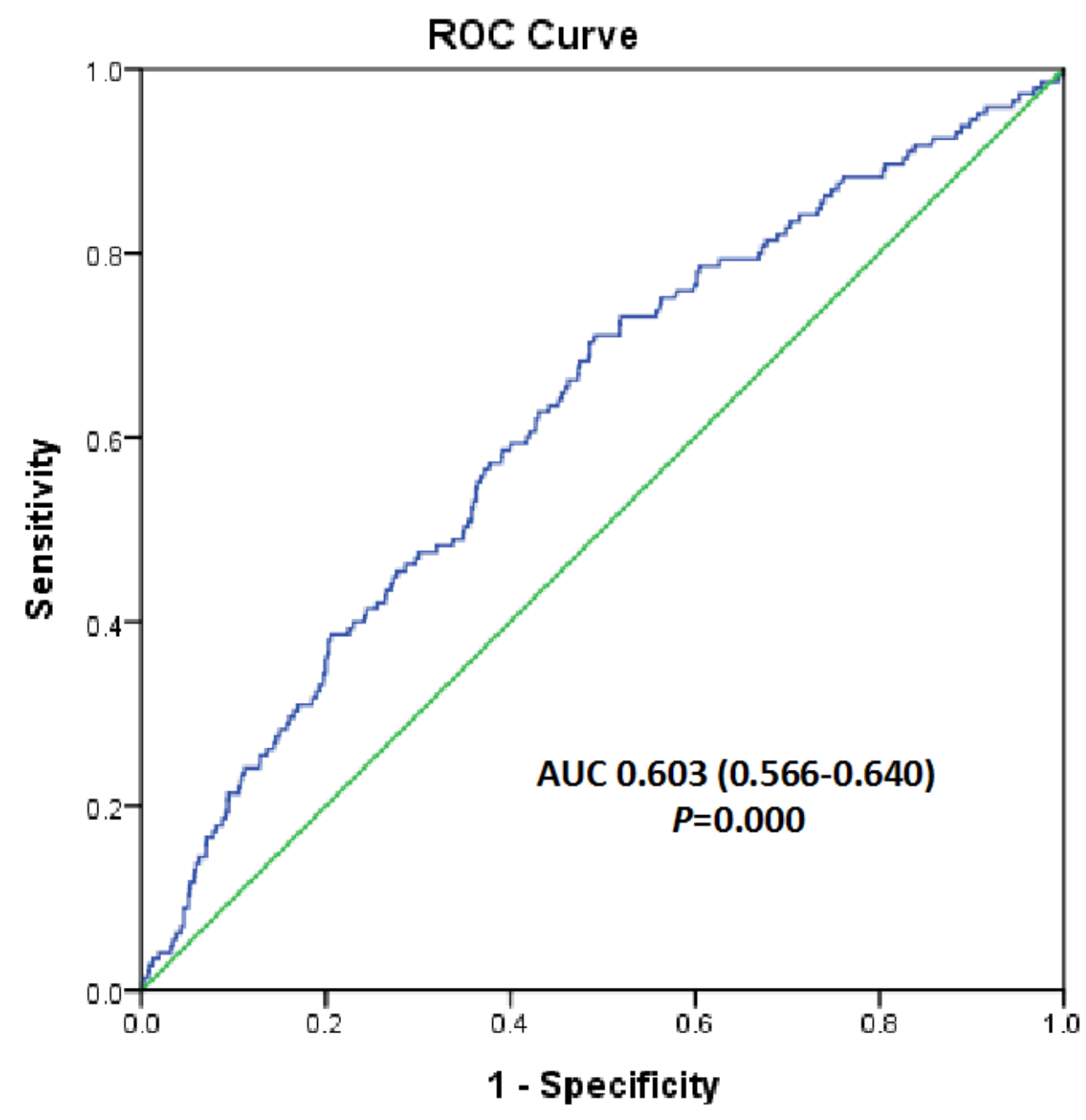

Figure 3

Receiver operating characteristic (ROC) curve of logarithmically transformed blood mercury levels for predicting overweight in Korean adolescents. Abbreviations: AUC, area under the ROC curve. 